\title{
Determination of amylose/amylopectin ratio of starches
}

\author{
Tatiéle Nalin $^{1,2}$ • Fernanda Sperb-Ludwig ${ }^{2}$ - Koen Venema ${ }^{3}$ 'Terry G. J. Derks ${ }^{4}$. \\ Ida Vanessa D. Schwartz ${ }^{1,2,5,6}$
}

Received: 29 March 2015 /Revised: 6 April 2015 / Accepted: 7 April 2015 /Published online: 29 April 2015

(C) SSIEM 2015

Dear editor,

Nalin et al 2014, in a paper recently published in the JIMD, tested in vitro digestion of seven different starches in a dynamic gastro-small intestine model (TIM-1), and did not find large differences between different brands of uncooked cornstarches (UCCS) and of a modified starch (Glycosade ${ }^{\circledR}$ ) (Correia et al 2008). However, the authors found that sweet polvilho, and the mixture of sweet polvilho and UCCS, seem to have a slower and extended release of glucose, which looks promising as an option for the treatment of diseases associated with fasting intolerance, such as hepatic glycogen storage diseases. We would like to report herein the experiment we performed to determine the percentage of amylose and

Communicated by: Bruce A Barshop

Ida Vanessa D. Schwartz

ischwartz@hcpa.ufrgs.br

1 Post-Graduation Program in Genetics and Molecular Biology, Universidade Federal do Rio Grande do Sul, Porto Alegre, Brazil

2 Laboratory of Basic Research and Advanced Investigations in Neurosciences, Hospital de Clínicas de Porto Alegre, Porto Alegre, Brazil

3 Beneficial Microbes Consultancy, Wageningen, The Netherlands

4 Section of Metabolic Diseases, Beatrix Children's Hospital, University Medical Center of Groningen, University of Groningen, Groningen, The Netherlands

5 Department of Genetics, Universidade Federal do Rio Grande do Sul, Porto Alegre, Brazil

6 Medical Genetics Service, Hospital de Clínicas de Porto Alegre, Rua Ramiro Barcelos, 2350, 90035-903 Porto Alegre, RS, Brazil amylopectin in the same starch samples analyzed by Nalin et al 2014.

Starch consists of a mixture of amylose (linear chain) and amylopectin (branched chain) (Tester et al 2004). The amylose/amylopectin ratio has an important influence on the rate and extent of starch digestion (Björck et al 1994), which may, in turn, influence the treatment of patients with fasting intolerance.

The amylose/amylopectin ratio was measured using a commercial kit (Megazyme Co., Wicklow, Ireland), according to the manufacturer's recommendations. For a better characterization of the sweet polvilho, we also analyzed two different batches of this product and, in addition, two samples of the same batch but with different expiration dates (Table 1).

The different brands of UCCS did not differ regarding the amylose/amylopectin ratio. As expected, the Glycosade ${ }^{\circledR}$ presented the highest amylopectin content. The sweet polvilho was found to present a slightly higher value of amylopectin compared to the UCCS. Furthermore, little variation was found between different batches or within the same batch of sweet polvilho, demonstrating the stability of the composition of this product (Table 1).

Although the data presented herein supports some of the findings described by Nalin et al 2014, e.g., different brands of UCCS present small differences among themselves, they did not explain the slower and lower digestibility found for sweet polvilho in the TIM-1 model. This is not a surprising finding since many other factors, besides the amylose/amylopectin ratio, may be responsible for the differences in the glucose and insulin responses, such as the solubility of the starch. Additional studies using the TIM-2, which includes the large intestine 
Table 1 Amylose/amylopectin ratio in the samples

\begin{tabular}{|c|c|c|c|c|}
\hline Samples ${ }^{\mathrm{a}}$ & Product & Origin & $\begin{array}{l}\text { Percentage } \\
\text { of amylose }\end{array}$ & $\begin{array}{l}\text { Percentage } \\
\text { of amylopectin }\end{array}$ \\
\hline $\operatorname{Argo}^{\circledR}$ & Cornstarch & USA & 28.7 & 71.3 \\
\hline GreatValue $^{\circledR}$ & Cornstarch & USA & 27.6 & 72.4 \\
\hline $\begin{array}{l}\text { Brazilian Maizena } \\
\text { Duryea }{ }^{\circledR}\end{array}$ & Cornstarch & $\mathrm{BR}$ & 27.8 & 72.2 \\
\hline Yoki $^{\circledR}$ & Cornstarch & $\mathrm{BR}$ & 27.4 & 72.6 \\
\hline $\begin{array}{c}\text { Dutch Maizena } \\
\text { Duryea }^{\circledR}\end{array}$ & Cornstarch & NL & 26.6 & 73.4 \\
\hline Glycosade ${ }^{\circledR}$ & Modified starch & UK & 8.0 & 92.0 \\
\hline Sweet polvilho* & Sweet polvilho & $\mathrm{BR}$ & 23.8 & 76.2 \\
\hline Sweet polvilho** & Sweet polvilho & $\mathrm{BR}$ & 22.2 & 77.8 \\
\hline $\begin{array}{l}\text { Sweet } \\
\text { polvilho*** }\end{array}$ & Sweet polvilho & BR & 21.9 & 78.1 \\
\hline
\end{tabular}

${ }^{a}$ Cornstarches and the modified starch samples are called by the brand; Sweet Polvilho brand: Fritz e Frida ${ }^{\circledR}$

BR, Brazil; NL, The Netherlands; UK, United Kingdom; USA, United States of America

*batch: 00113

**batch: 00114; expiration date: Jun 22, 2016

***batch: 00114; expiration date: Sep 22, 2016

model, or even clinical trials, should be performed to better characterize the effect of sweet polvilho in the treatment of fasting intolerance.
Acknowledgments The authors thank David Weinstein and Carolina F. Moura de Souza for fruitful discussions. They also thank the CAPES Foundation/Ministry of Education of Brazil, CNPq Foundation/Ministry of Science, Technology, and Innovation of Brazil [T.N.], Fundação de Amparo à Pesquisa do Rio Grande do Sul [Post-doctorate fellowship to F.S.L.], CNPq Foundation - Chamada $N^{\circ}$ 31/2013 - Doenças Metabólicas e Endócrinas, and FAPERGS Foundation - PPSUS/2013.

Competing interest Tatiéle Nalin, Fernanda Sperb-Ludwig, Koen Venema, Terry G J Derks, and Ida V D Schwartz declare that they have no conflict of interest.

Human and Animal Rights and Informed Consent This article does not contain any studies with human or animal subjects performed by any of the authors.

\section{References}

Björck I, Granfeldt Y, Liljeberg H, Tovar J, Asp NG (1994) Food properties affecting the digestion and absorption of carbohydrates. Am J Clin Nutr 59:S699-S705

Correia CE, Bhattacharya K, Lee PJ et al (2008) Use of modified cornstarch therapy to extend fasting in glycogen storage disease types Ia and Ib. Am J Clin Nutr 88:1272-1276

Nalin T, Venema K, Weinstein DA et al (2014) In vitro digestion of starches in a dynamic gastrointestinal model: an innovative study to optimize dietary management of patients with hepatic glycogen storage diseases. J Inherit Metab Dis. doi:10.1007/s10545-0149763-y

Tester RF, Karkalas J, Qi X (2004) Starch structure and digestibility enzyme-substrate relationship. Worlds Poult Sci J 60:186-195 